\title{
Visual Impairment and Smart Cities: Perspectives on Mobility
}

\author{
Caio Henrique Marques Texeira ${ }^{1 *}$, Aline Sutili Toledo ${ }^{2}$, Amanda da Silva Amorim ${ }^{3}$, Sergio Takeo Kofuji ${ }^{4}$ and \\ Vagner Rogério dos Santos ${ }^{5}$
}

${ }^{1}$ GS Ophtalmic Medical Techonologist, Universidade Federal de São Paulo, SP, Brazil.

${ }^{2}$ MD. Escola Paulista de Medicina, ophthalmology and Visual Science Department, Universidade Federal de São Paulo, SP,Brazil.

${ }^{3}$ GS. Economics, Pontifícia Universidade Católica, SP, Brazil

${ }^{4}$ GS. Economics, Pontifícia Universidade Católica, SP, Brazil.

${ }^{5}$ PhD. Visual Rehabilitation and Ocular Bioengineering, Ophthalmology and Visual Science Department, Universidade Federalde São Paulo, SP, Brazil.

Submission: April 15, 2017; Published: June 08, 2017

*Corresponding author: Caio Henrique Marques Texeira, GS Ophtalmic Medical Techonologist, Federal university of de São Paulo, Brazil, Tel: 5511 96632-498; Email: caiomtex@hotmail.com

Abstract

Introduction: Visually impaired people face many problems when it comes to urban mobility, even though law guarantees their rights. Many of them are able to guide well themselves using white canes and tactile devices, but they still needs some help from the others to successfully complete their journey or assignment, which reduces their autonomy or even their safety. When using public transportation, the visually impaired report lack of awareness and sensitivity of people in general. Improvements of labor field are also important in order to evidence the value of the visually challenged manpower to economy, exercising social inclusion and meliorating their self-esteem. Thus, the idea of a smart city is extremely relevant, because it characterizes progress of infrastructure and services using technology, making city administration, education, public security, health service, housing and transportation even more connected and efficient. The purpose of this study is to show that the combination between concepts related to mobility of unsighted people and to smart cities results in benefits for both the visually impaired and the society.

Discussion: Improving visually impaired autonomy in mobility gathering concepts based on smart cities.

Conclusion: The fusion of concepts related to visual impairment and smart cities is extremely beneficial for autonomy, mobility and economy. Keywords: Visual impairment; Autonomy; Technology; Mobility; Job market; Smart cities, White cane

\section{Introduction}

The term "visual impairment" refers to irreversible visual loss, even after medical treatment. World Health Organization (WHO) classifies visual function in 4 levels: normal vision, moderate visual impairment, severe visual impairment and blindness. Moderate visual impairment combined with severe visual impairment under the term "low vision". Individual with this condition, despite the visual loss, is able to plan and/or execute assignments. About $1 \%$ of the world population presents some kind of visual deficiency, and more than $90 \%$ of those are distributed in third world countries [1].

Visual loss can be either congenital or acquired. A person who had developed blindness during his life has visual memories, thus, such memories are preserved. However, those who were born blind will not have the capacity of forming visual images, but they will develop strategies in order to structure a mental representation of space. Unsighted people normally use sonorous, kinesthetic, tactile, thermal and olfactory information through reminiscent senses [2]. In those cases, moving through places requires sensor-motor-cognitive skills, including perception, codification, learning and space information recall. That assignment can be stressfull, especially for the existence of two factors that directly affects the process of space orientation: environment layout and environment quality information [2].

Even though law guarantees their rights, visually impaired people face many problems when it comes to urban mobility. Many of them are able to guide well themselves using white 
canes and tactile devices, but they still needs some help from others to successfully complete their journey or assignment, which reduces their autonomy or even their safety. When using public transportation, the visually impaired report lack of awareness and sensitivity of people in general and the need of help to inform bus destination, for example [2].

Absence of great urban mobility results in negative consequences not only for people's life quality, but also for economy, including factors that influence since Brazilian social security till the indexes of productivity and of competitiveness at job market [3]. Is doubtless that mobility technology facilitates the access to visual, tactile, olfactory and sonorous information through systems like Braille, conventional canes, especial boards, etc. It's concession should be considered as an integrant and an indispensable part of the rehabilitation or habilitation process [4].

Nowadays, new mobility technology is emerging such as electronic canes, which integrate the information given by the ultrasound sensor to the traditional cane characteristics, maintaining the touch technique used in independent dislocation [1]. Another example is WAYFINDR( $\mathbb{R}$ ) App that uses beacons (proximity device that sends information), Bluetooth, headphones, bone conduction and the smart phone itself, permitting visually impaired people to walk on streets in a more independent way [5].

The concept of a smart city includes also an idea of urban management based on Technology of Information and Communication [3], using hardware and software as sensors, Radio Frequency Identification (RFID), beacons, and other items related to de Internet of Things concept (IoT) [6-8]. Many of the technologies applied resort to Global Positioning System (GPS) for the purpose of collecting location data. However, GPS can suffer interference from obstacles which hind satellite's signal propagation, as indoor places, where signal hardly can be captured with enough quality. Thereby, other forms to localization will be required, as well as inertial sensors or ultrasound pulses [9].

Accordingly, at smart cities will be possible monitoring, localization and geo referencing actions, traffic preventive maintenance, alternative transportation and itinerary and route information. Users also can report urban accessibility features trough their ride, describing street and sidewalk conditions, for an example [3]. The purpose of the present study is to show that the combination between concepts related to mobility of unsighted people and to smart cities results in benefits for both the visually impaired and the society.

\section{Discussion}

A person who is blind or has low vision faces many adversities during the day. Those difficulties goes since obstacles in the way till poor infrastructure on educational and on professional fields [5]. Among the most common structural problems are bumpy sidewalks and few or none signaling, making harder and dangerous to cross streets [10]. In general, the visually impaired recur to some instruments that give space orientation on urban mobility and they are directly influenced by the city infrastructure [4].

I. White cane pencil tip: ideal for places still unknown. Enables different types of soil identification by vibration and sounds produced [4].

II. White cane roller tip: used for space recognition at places without many obstacles [4].

III. Walls: are used as a safety reference for the visually challenge [4].

IV. Lowered sidewalks: offer risks when tactile floor is not present to indicate where the sidewalk starts [4].

V. Tactile floor: very helpful, but needs to be perfectly installed in order to preserve its information [4].

VI. Urban furniture: benches, trashcans, street sings, bus stop, telephone cabins, etc [4].

Another aspect of a poor urban mobility is the negatives consequences for city economy, mentioning the impact on Brazilian social security when it comes to the occurrence of accidents and to the raise of governmental pensions; besides productivity reduction as the employee spends extra time and effort commuting to work [3].

Difficulties are present also on the job market. To professional qualify and to be competitive can be a great challenge for people who suffer from visual loss. Thus, assistant technology is indispensable because it provides more independency for the visually impaired and freedom to do everyday duty in a plainer way. Yet, technology incentive, especially for mobility, is extremely important and even determinant to insert this group in professional, educational and social communication spheres, making them participatory in society [11]. Some projects have already been developed, as WAYFINDR $($ App. That system recurs location data given by beacons via Bluetooth to define one's location, then, audio instructions are created to guide the individual trough the space, avoiding dangerous spots, permitting people to reach their destination safer and faster [5].

There are also some projects of the so-called smart canes [1].

I. E Touch cane: is known as the "speakerphone cane" .It has Global Positioning System (GPS), voice recognition and headphones, by which the visually impaired, indicates its starting point and destination by voice command [1].

II. «Low Cost» electronic cane: it has two sensors that warn the visually impaired when there is some obstacle within a certain distance [1].

III. «Smart» electronic cane: created by the Universität Konstanz, this type of electronic cane is able to trace routes 
and identify signs that have Quick Response codes (QR codes) to help the user cross streets or find establishments [1].

IV. Smart Cane: developed by students at the University of Michigan, can recognize radio frequency identification tags located along the route [1].

It is important to note that with the advent of generations of communities and services that have the Web conception as a platform, possibilities of information dissemination and data sharing have increased. That fact happened due to popularization of Internet and to increased shared data flow, allowing the user to participate in creation of content. That is a great contribution for many smart cities tools [9]. The collected and processed data make possible to plan some action such as details about the path where the user travels with his smart cane, after processing references about the place. That technology should also be used at environments as school, work or home [3].

A smart city uses information and communication technology resources, providing more interactivity in order to improve its infrastructure and its public services in general, making that administration, education, health service, public security, and housing and transportation sectors even more connected and efficient. Technology is the starting point for a smart city [8].

\section{Conclusion}

It is possible to infer that through the fusion between the concepts of Technology of Information and Communication applied in auxiliary devices for people with visual impairment and the idea of smart cities has a positive impact on these people's life quality. Therefore, the greater autonomy of the visually impaired results in greater self-esteem, better security and ensure competitiveness in job market. In addition, infrastructure is benefited with improvements generating more interactivity and development for the city.

\section{Acknowledgement}

We are grateful to CNPq for the Technological and Industrial Initiation grant A granted by process no 180180/ 2017-7 for the project "Support magnifying glass with color change and adjustment of light intensity for visual rehabilitation" to student Caio Henrique Marques Texeira.

\section{References}

1. Santos JP dos, Forest JD, Dutra GA, Almeida M de Uma, Avaliação (2012) Da Bengala Eletrônica (Tecnologia Assistiva), Para A Melhoria De Mobilidade Dos Deficientes Visuais.

2. Santos MSS, Costa ADL (2015) A Orientação Físico-Espacial De Pessoas Com Deficiência Visual: Conhecendo 0 Usuário. Revista Nacional De Gerenciamento De Cidades 3(15).

3. Andrade JN, Galvão DC (2016) O Conceito De Smart Cities Aliado À Mobilidade Urbana. REVISTA HUM@ NAE, 10(1).

4. Sampaio MW, Haddad MAO, da Costa Filho HA, de Campos Siaulys MO (2010) Baixa Visão E Cegueira: Os Caminhos Para A Reabilitação, A Educação E A Inclusão (1 $1^{\text {st }}$ edn), Cultura Médica E Guanabara Koogan, Rio De Janeiro, Brazil, p: 552.

5. Lopes BG (2015) A Tecnologia Como Meio De Inclusão Dos Deficientes Visuais No Transporte Público. Iniciação-Revista De Iniciação Científica, Tecnológica E Artística Edição Temática Em Tecnologia Aplicada. São Paulo 5(4).

6. Wendling M (2010) Sensores. Universidade Estadual Paulista. São Paulo.

7. Loureiro AF (2002) Redes De Sensores Sem Fio. Minas Gerais.

8. Prata PI (2008) Sistemas De Localização Para Ambientes Interiores Baseados Em RFID. Universidade De Aveiro.

9. Aquino ALL (2015) Cidades Inteligentes, Um Novo Paradigma Da Sociedade Do Conhecimento. Blucher Education Proceedings 1(1): 165-178.

10. Gouveia DRS de, Ferreira WRB, Borges MA, Gonçalves RS (2010) Desenvolvimento De Uma Bengala Eletrônica Para Locomoção De Pessoas Com Deficiência Visual.

11. Ferreira MV (2015) Trabalho Decente E Inclusão Social: A Inserção Da Pessoa Com Deficiência Visual No Mercado De Trabalho Como Afirmação De Sua Cidadania. Rio De Janeiro.

\begin{tabular}{|l|}
\hline \multicolumn{1}{|c|}{ Your next submission with Juniper Publishers } \\
will reach you the below assets \\
- Quality Editorial service \\
- Swift Peer Review \\
- Reprints availability \\
- E-prints Service \\
- Manuscript Podcast for convenient understanding \\
- Global attainment for your research \\
- Manuscript accessibility in different formats \\
( Pdf, E-pub, Full Text, Audio) \\
- Unceasing customer service \\
Track the below URL for one-step submission \\
https://juniperpublishers.com/online-submission.php \\
\hline
\end{tabular}

